.. Sedlar, Šefc, Drvodelić, Jambreković, Kučinić, Ištok: Physical Properties of Juvenile Wood...

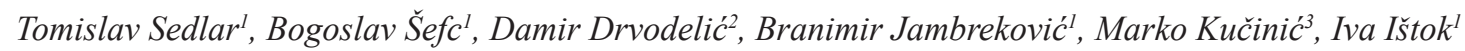

\title{
Physical Properties of Juvenile Wood of Two Paulownia Hybrids
}

\section{Fizička svojstva juvenilnog drva dvaju hibrida paulovnije}

\author{
Original scientific paper • Izvorni znanstveni rad \\ Received-prispjelo: 20. 10. 2019. \\ Accepted-prihvaćeno: 28. 4. 2020. \\ UDK: $630 * 812.23 ; 630 * 812.31 ; 630 * 815.321$ \\ https://doi.org/10.5552/drvind.2020.1964
}

(C) 2020 by the author(s). Licensee Faculty of Forestry, University of Zagreb. This article is an open access article distributed under the terms and conditions of the Creative Commons Attribution (CC BY 4.0) license.

\begin{abstract}
There is a growing trend in the world of planting fast growing species (rotations 5 to 10 years). Their primary purpose is the production of wood fibers and biomass, but they certainly represent the potential in making solid wood products as well. One of the fast-growing species is Paulownia sp., a species of extremely fast growing wood. Plantation breeding of Paulownia sp. in Croatia is increasing, although there is a little knowledge about the technical properties of Paulownia wood and its end use is questionable. This paper presents preliminary results of some physical properties of juvenile wood of two Paulownia hybrids planted in the area near the town of Glina in the Republic of Croatia. One hybrid is 9501 ( ( Paulownia fortunei $\times$ Paulownia elongata $) \times(\underline{\text { Paulownia }}$ fortunei $\times$ Paulownia tomentosa) $)$ and the other hybrid is Shan Tong (Paulownia fortunei $\times$ Paulownia tomentosa). The aim of this study was to investigate physical properties of juvenile wood of two Paulownia hybrids from one site in Croatia, to determine differences in physical properties of wood between two hybrids and to evaluate the correlation between density and shrinkages of each hybrid. Significant differences in oven dry density, basic density and density at maximum MC, between the two hybrids were determined. There is no statistically significant difference in longitudinal, radial, tangential and volumetric shrinkages between the two hybrids.
\end{abstract}

Keywords: hybrid 9501; hybrid Shan Tong; juvenile wood; Paulownia wood; physical properties

SAŽETAK • U današnje je vrijeme zamjetan sve češći trend sadnje brzorastućih vrsta drveća (ophodnje od 5 do 10 godina). Te su vrste primarno namijenjene proizvodnji drvnih vlakana i biomase, ali svakako je vidljiv $i$ njihov potencijal u proizvodima od cjelovitog drva. Jedna od brzorastućih vrsta je Paulownia sp., koju odlikuje izrazito brz rast. Iako se malo zna o tehničkim svojstvima drva paulovnije, a njegova je krajnja upotreba upitna, u Hrvatskoj je u porastu plantažni uzgoj paulovnije. U ovom su radu prikazani preliminarni rezultati istraživanja nekih fizičkih svojstava juvenilnog drva hibrida paulovnije s lokaliteta u blizini grada Gline u Hrvatskoj. Prvi je hibrid 9501 ((Pau-

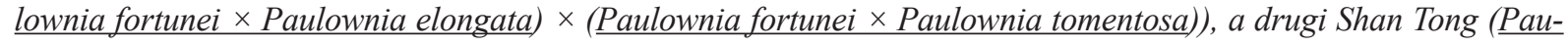
lownia fortunei $\times$ Paulownia tomentosa). Cilj rada bio je istražiti fizička svojstva juvenilnog drva hibrida paulovnije s lokaliteta u Hrvatskoj, utvrditi razlike u fizičkim svojstvima drva tih hibrida te odrediti međusobni odnos gustoće $i$ utezanja unutar hibrida. Utvrđene su značajne razlike u gustoći drva u apsolutno suhom stanju, u nominalnoj gustoći i gustoći pri maksimalnom sadržaju vode između tih dvaju hibrida. Među hibridima nisu utvrđene statistički značajne razlike u longitudinalnome, radijalnome, tangentnome ni volumnom utezanju.

Ključne riječi: hibrid 9501; hibrid Shan Tong; juvenilno drvo; drvo paulovnije; fizička svojstva

\footnotetext{
${ }^{1}$ Authors are assistant professor, associate professor, assistant and senior assistant at University of Zagreb, Institute of Wood Science, Faculty of Forestry, Zagreb, Croatia.

2 Author is assistant professor at University of Zagreb, Institute of Ecology and Silviculture, Faculty of Forestry, Zagreb, Croatia.

${ }^{3}$ Author is student at University of Zagreb, Faculty of Forestry, Zagreb, Croatia.
} 


\section{INTRODUCTION}

\section{UVOD}

The trend of increasing demand for wood raw material is becoming of great global concern. The answer to this would be to plant more fast growing trees of different species, in order to conserve native forests and to ensure adequate supplies of wood. Paulownia $\mathrm{sp}$. is an example of very adaptable genus requiring minimal management after the first few years (ElShowk, 2003). It has been cultivated throughout Asia for centuries, with China having the longest history (Ates et al., 2008).

Paulownia wood is considered to be extremely fast growing, especially in the juvenile phase of growth. Under optimal conditions, Paulownia sp. trees can produce useful timber within five to six years, measuring $30-40 \mathrm{~cm}$ in diameter after ten years (Olson and Carpenter, 1982; Zhao-Hua et al., 1986). It is widely used for various purposes, with excellent prospects for pulp and biomass (Vilotić et al., 2015; Icka et al., 2016; Vusić et al., 2018). However, as a solid wood, it is suggested to be used in products that are not subject to great loads during exploitation (Šoškić et al., 2003) and not for structural purposes (Koman et al., 2017).

Due to its high adaptability, new markets are developing rapidly for plantation grown Paulownia sp. in many countries. In Croatia, the most commonly propagated are Paulownia hybrids Shan Tong and 9501. Currently, there are no Paulownia hybrid trees with known origin older than four years in Croatia. Drvodelić (2018) investigated their propagation by root cuttings, where the difference in rooting percentage between two hybrids depended on the cutting thickness and drying procedure. However, technical properties of hybrids 9501 and Shan Tong have not been investigated so far in Croatia. In addition, there are limited data on technical properties of wood of different Paulownia species (Ayhildiz and Kol, 2010; Kiaei, 2013; San et al., 2016; Komán et al., 2017).

Therefore, data on properties of Paulownia hybrid wood grown on the territory of the Republic of Croatia are needed. This information could determine whether Paulownia sp. is profitable for cultivation and use as a raw material for industrial purposes.

The aim of this study was to investigate physical properties of Paulownia hybrids 9501 and Shang Tong juvenile wood from one site in the Republic of Croatia, to determine differences in physical properties of wood between two hybrids and to evaluate the correlation between density and shrinkages of each hybrid.

\section{MATERIALS AND METHODS}

\section{MATERIJALI I METODE}

For the purpose of this research, two 4-year old Paulownia hybrids were taken from the area near the town of Glina in Croatia. One hybrid is 9501 ((Paulownia fortunei $\times$ Paulownia elongata $) \times($ Paulownia fortunei $\times$ Paulownia tomentosa) ) and the other hybrid is Shan Tong (Paulownia fortunei $\times$ Paulownia tomento- $s a)$. Five test trees of each hybrid were taken from the experimental stand. All trees were chosen as representative of the stand according to HRN ISO 3129:2015.

Four disks were cut at breast height $(1.3 \mathrm{~m})$, upwards to the crown, from each tree. Disks were approximately $5 \mathrm{~cm}$ thick and $10 \mathrm{~cm}$ in diameter. Maximum number of test samples were cut from each disk, according to HRN ISO 3129:2015.

Physical properties determined in this study were density in absolutely dry condition, basic density and density at maximum moisture content (HRN ISO 13061-2:2015); longitudinal, radial and tangential shrinkage (ISO 13061-13:2016); volumetric shrinkage (ISO 13061-14:2016) and maximum moisture content (HRN ISO 13061-1:2015).

Statistical analysis of data and their comparison were carried out in Statistica 8. Data were analyzed and presented as the minimum, mean and maximum values, as well as standard deviation. The analysis of variance (ANOVA) was used to determine whether there are any statistically significant differences between the means of investigated wood properties of two Paulownia hybrids. Duncan's multiple range test (DMRT) was applied to test statistical significance at $\alpha=0.05$ level. The simple linear regression model was used to analyze the relationship between density and shrinkage.

\section{RESULTS AND DISCUSSION 3. REZULTATI I RASPRAVA}

Statistical values of Paulownia hybrids 9501 and Shan Tong juvenile wood, as well as the summary of analysis of variance (ANOVA) for oven dry density, basic density, density at maximum moisture content (MC), longitudinal, radial, tangential, and volumetric shrinkage are shown in Table 1, Table 3, Figure 1 and Figure 2.

Physical properties of wood, especially wood density and dimensional stability, are important factors affecting wood quality (Ištok et al., 2016). Mean oven dry density of hybrid 9501 is $249 \mathrm{~kg} / \mathrm{m}^{3}$ and of hybrid Shan Tong is $237 \mathrm{~kg} / \mathrm{m}^{3}$ (Table 1 ). The analysis of variance (ANOVA) indicated that there is significant difference in oven dry density between the two hybrids (Table 3). However, these differences in mean values amounted only to about $6 \%$. The values are similar to the findings on Paulownia elongata, $240 \mathrm{~kg} / \mathrm{m}^{3}$ (Šoškić et al., 2003); Paulownia tomentosa, $276 \mathrm{~kg} / \mathrm{m}^{3}$ (Komán et al., 2017); Paulownia fortunei, $274 \mathrm{~kg} / \mathrm{m}^{3}$ (Šsoškić et al., 2017) and $261 \mathrm{~kg} / \mathrm{m}^{3}$ (Kiaei, 2013).

For hybrid 9501, the mean value of longitudinal shrinkage is $0.30 \%$, radial shrinkage $2.35 \%$, tangential shrinkage $4.95 \%$ and volumetric shrinkage $7.62 \%$ (Table 1). For hybrid Shan Tong, the mean value of longitudinal shrinkage is $0.35 \%$, radial shrinkage $2.47 \%$, tangential shrinkage $5.30 \%$ and volumetric shrinkage 7.81 $\%$ (Table 1). The analysis of variance (ANOVA) indicated that there is no significant difference in shrinkages between the two hybrids (Table 3 ). Very high variability of longitudinal shrinkage is present. This could be explained by low age of investigated trees, closely to juve- 
.. Sedlar, Šefc, Drvodelić, Jambreković, Kučinić, Ištok: Physical Properties of Juvenile Wood...

Table 1 Descriptive statistical analysis of physical properties between Paulownia hybrids 9501 and Shan Tong

Tablica 1. Deskriptivna statistička analiza fizičkih svojstava hibrida paulovnije 9501 i Shan Tong

\begin{tabular}{|c|c|c|c|c|c|c|}
\hline $\begin{array}{l}\text { Property } \\
\text { Svojstvo }\end{array}$ & $\begin{array}{l}\text { Hybrid } \\
\text { Hibrid }\end{array}$ & \begin{tabular}{|c|} 
Number of \\
samples \\
Broj uzoraka \\
\end{tabular} & \begin{tabular}{|c|} 
Mean $^{\mathbf{a}}$ \\
Srednja \\
vrijednost $^{a}$ \\
\end{tabular} & $\begin{array}{c}\text { Standard deviation } \\
\text { Standardna } \\
\text { devijacija }\end{array}$ & Min & Max \\
\hline \multirow{2}{*}{$\begin{array}{l}\text { Oven dry density } \\
\text { gustoća u apsolutno suhom stanju }\end{array}$} & 9501 & 34 & $0.249 \mathrm{a}$ & 0.016 & 0.221 & 0.295 \\
\hline & Shan Tong & 34 & $0.237 \mathrm{~b}$ & 0.019 & 0.201 & 0.277 \\
\hline \multirow{2}{*}{ Basic density / nominalna gustoća } & 9501 & 34 & $0.233 \mathrm{a}$ & 0.014 & 0.208 & 0.272 \\
\hline & Shan Tong & 34 & $0.220 \mathrm{~b}$ & 0.017 & 0.187 & 0.252 \\
\hline \multirow{2}{*}{$\begin{array}{l}\text { Density at maximum } \mathrm{MC} \\
\text { gustoća pri maksimalnom sadržaju vode }\end{array}$} & 9501 & 34 & $0.719 \mathrm{a}$ & 0.078 & 0.600 & 0.917 \\
\hline & Shan Tong & 34 & $0.669 \mathrm{~b}$ & 0.063 & 0.562 & 0.850 \\
\hline \multirow{2}{*}{$\begin{array}{l}\text { Longitudinal shrinkage } \\
\text { longitudinalno utezanje }\end{array}$} & 9501 & 34 & $0.30 \mathrm{a}$ & 0.202 & 0.04 & 0.74 \\
\hline & Shan Tong & 34 & $0.35 \mathrm{a}$ & 0.332 & 0.04 & 1.20 \\
\hline \multirow{2}{*}{ Radial shrinkage / radijalno utezanje } & 9501 & 34 & $2.35 \mathrm{a}$ & 0.489 & 1.61 & 3.42 \\
\hline & Shan Tong & 34 & $2.47 \mathrm{a}$ & 0.631 & 1.67 & 4.69 \\
\hline \multirow{2}{*}{ Tangential shrinkage / tangentno utezanje } & 9501 & 34 & $4.95 \mathrm{a}$ & 0.643 & 4.05 & 6.26 \\
\hline & Shan Tong & 34 & $5.30 \mathrm{a}$ & 0.969 & 3.80 & 8.02 \\
\hline \multirow{2}{*}{ Volumetric shrinkage / volumno utezanje } & 9501 & 34 & $7.62 \mathrm{a}$ & 0.966 & 6.07 & 9.38 \\
\hline & Shan Tong & 34 & $7.81 \mathrm{a}$ & 1.409 & 5.13 & 11.21 \\
\hline Maximum MC / maksimalni sadržaj vode & 9501 & 34 & $208 \mathrm{a}$ & 19.432 & 172 & 253 \\
\hline
\end{tabular}

${ }^{a}$ Rresults with different letters have a significant difference with the Duncan's test. / Rezultati s različitim slovima statistički se značajno razlikuju prema Duncanovu testu.

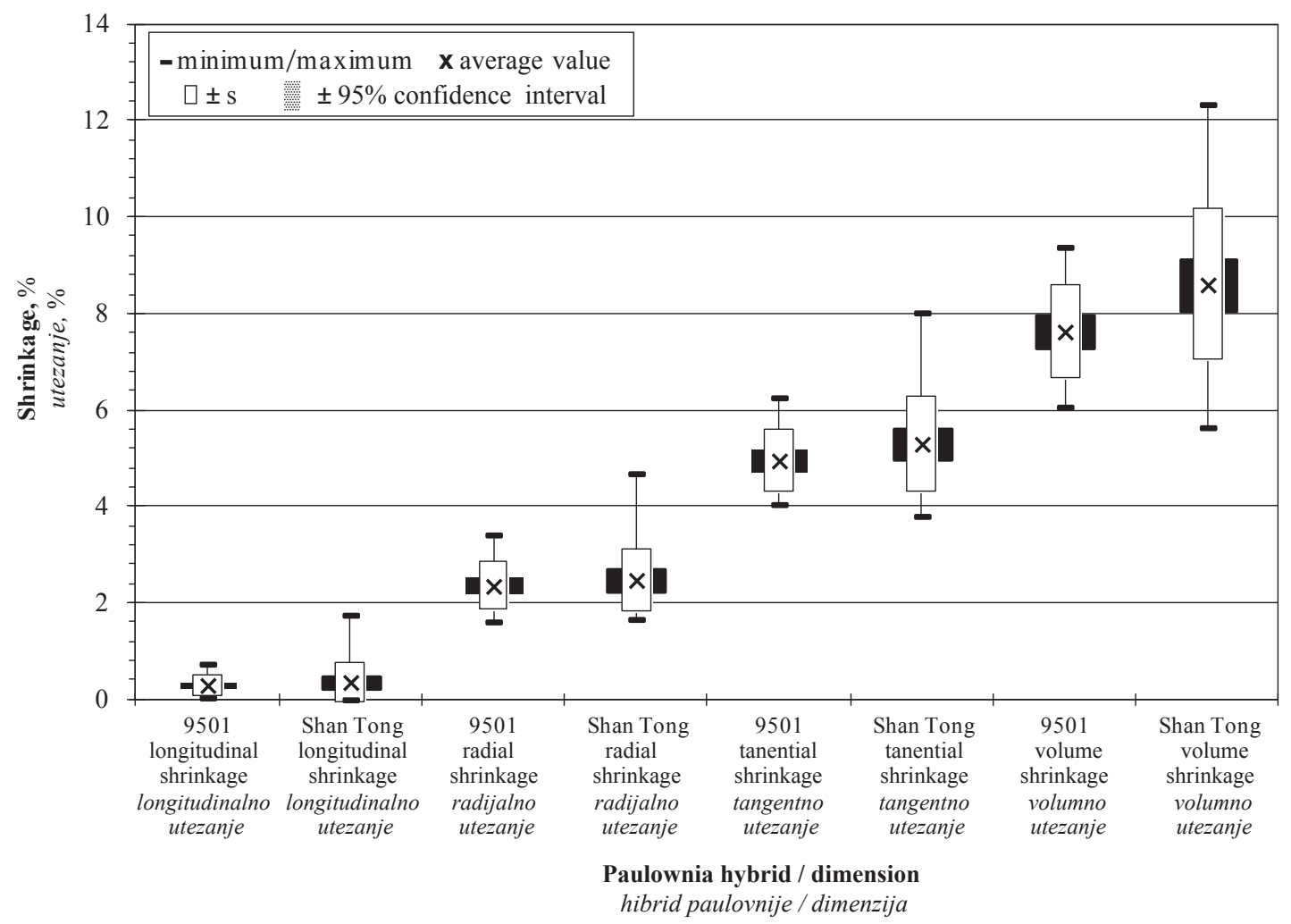

Figure 1 Statistical analyses of longitudinal, radial, tangential and volume shrinkage, between two paulownia hybrids Slika 1. Statistička analiza longitudinalnoga, radijalnoga, tangentnoga i volumnog utezanja, dvaju hibrida paulovnije

Table 2 Comparison of shrinkage values with references

Tablica 2. Usporedba vrijednosti utezanja s rezultatima iz literature

\begin{tabular}{|l|c|c|c|c|c|c|}
\hline \multicolumn{1}{|c|}{$\begin{array}{c}\text { Property } \\
\text { Svojstvo }\end{array}$} & $\begin{array}{c}\text { Hybrid } \\
\mathbf{9 5 0 1} \\
\text { (our research) } \\
\text { Hybrid } \\
\text { 9501 (vlastito } \\
\text { istraživanje) }\end{array}$ & $\begin{array}{c}\text { Hybrid } \\
\text { Shan Tong } \\
\text { (our research) } \\
\text { Hybrid } \\
\text { Shan Tong } \\
\text { (vlastito } \\
\text { istraživanje) }\end{array}$ & $\begin{array}{c}\boldsymbol{P} . \\
\text { elongata } \\
\text { (Šoškić } \\
\text { et al., } \\
\mathbf{2 0 0 3}\end{array}$ & $\begin{array}{c}\boldsymbol{P} . \\
\text { fortunei } \\
\text { (Šoškić } \\
\text { et al., } \\
\mathbf{2 0 0 3}\end{array}$ & $\begin{array}{c}\boldsymbol{P} . \\
\text { tomentosa } \\
\text { (Kiaei, } \\
\mathbf{2 0 1 3}\end{array}$ & $\begin{array}{c}\boldsymbol{P} . \\
\text { fortunei } \\
\text { (Komán } \\
\text { et al., } \\
\mathbf{2 0 1 7}\end{array}$ \\
\hline Radial shrinkage / radijalno utezanje & 2.35 & 2.47 & 2.49 & 2.54 & - & 2.20 \\
\hline Tangential shrinkage / tangentno utezanje & 4.95 & 5.30 & 4.74 & 4.79 & - & 3.89 \\
\hline Volumetric shrinkage / volumno utezanje & 7.62 & 7.81 & 8.31 & 8.35 & 7.54 & 6.94 \\
\hline
\end{tabular}


Sedlar, Šefc, Drvodelić, Jambreković, Kučinić, Ištok: Physical Properties of Juvenile Wood... ..

Table 3 Analysis of variance (ANOVA) results for physical properties between Paulownia hybrids 9051 and Shan Tong juvenile wood

Tablica 3. Analiza varijance (ANOVA) fizičkih svojstava juvenilnog drva hibrida paulovnije 9051 i Shan Tong

\begin{tabular}{|c|c|c|c|c|c|c|}
\hline $\begin{array}{l}\text { Property } \\
\text { Svojstvo }\end{array}$ & $\begin{array}{c}\text { Effect } \\
\text { Varijabilnost }\end{array}$ & $\begin{array}{c}\text { Sum of } \\
\text { squares } \\
\text { Suma } \\
\text { kvadrata }\end{array}$ & $\begin{array}{l}\text { Degree of } \\
\text { freedom } \\
\text { Stupnjevi } \\
\text { slobode }\end{array}$ & $\begin{array}{c}\text { Mean square } \\
\text { Varijanca }\end{array}$ & $\mathrm{F}$ & $\mathrm{p}$ \\
\hline \multirow{3}{*}{$\begin{array}{l}\text { Oven dry density } \\
\text { gustoća u apsolutno suhom } \\
\text { stanju }\end{array}$} & Between Groups / između grupa & 0.003 & 1 & 0.003 & 8.41 & 0.005 \\
\hline & Within Groups / unutar grupa & 0.020 & 66 & 0.000 & & \\
\hline & Total / ukupno & 0.023 & 67 & & & \\
\hline \multirow{3}{*}{$\begin{array}{l}\text { Basic density } \\
\text { nominalna gustoća }\end{array}$} & Between Groups / između grupa & 0.003 & 1 & 0.003 & 12.67 & 0.000 \\
\hline & Within Groups / unutar grupa & 0.015 & 66 & 0.000 & & \\
\hline & Total / ukupno & 0.018 & 67 & & & \\
\hline \multirow{3}{*}{$\begin{array}{l}\text { Density at maximum } \mathrm{MC} \\
\text { gustoća pri maksimalnom } \\
\text { sadržaju vode }\end{array}$} & Between Groups / između grupa & 0.043 & 1 & 0.043 & 8.649 & 0.005 \\
\hline & Within Groups / unutar grupa & 0.329 & 66 & 0.005 & & \\
\hline & Total / ukupno & 0.372 & 67 & & & \\
\hline \multirow{3}{*}{$\begin{array}{l}\text { Longitudinal shrinkage } \\
\text { longitudinalno utezanje }\end{array}$} & Between Groups / između grupa & 0.513 & 1 & 0.051 & 0.678 & 0.413 \\
\hline & Within Groups / unutar grupa & 4.990 & 66 & 0.076 & & \\
\hline & Total / ukupno & 5.503 & 67 & & & \\
\hline \multirow{3}{*}{$\begin{array}{l}\text { Radial shrinkage } \\
\text { radijalno utezanje }\end{array}$} & Between Groups / između grupa & 0.262 & 1 & 0.262 & 0.822 & 0.368 \\
\hline & Within Groups / unutar grupa & 21.028 & 66 & 0.319 & & \\
\hline & Total / ukupno & 21.290 & 67 & & & \\
\hline \multirow{3}{*}{$\begin{array}{l}\text { Tangential shrinkage } \\
\text { tangentno utezanje }\end{array}$} & Between Groups / između grupa & 2.038 & 1 & 2.038 & 3.014 & 0.087 \\
\hline & Within Groups / unutar grupa & 44.634 & 66 & 0.676 & & \\
\hline & Total / ukupno & 46.672 & 67 & & & \\
\hline \multirow{3}{*}{$\begin{array}{l}\text { Volumetric shrinkage } \\
\text { volumno utezanje }\end{array}$} & Between Groups / između grupa & 4.244 & 1 & 4.244 & 2.722 & 0.103 \\
\hline & Within Groups / unutar grupa & 102.903 & 66 & 1.559 & & \\
\hline & Total / ukupno & 107.147 & 67 & & & \\
\hline \multirow{3}{*}{$\begin{array}{l}\text { Maximum MC } \\
\text { maksimalni sadržaj vode }\end{array}$} & Between Groups / između grupa & 233.0 & 1 & 233.0 & 0.628 & 0.430 \\
\hline & Within Groups / unutar grupa & 24491.0 & 66 & 0.781 & & \\
\hline & Total / ukupno & 24724.0 & 67 & & & \\
\hline
\end{tabular}

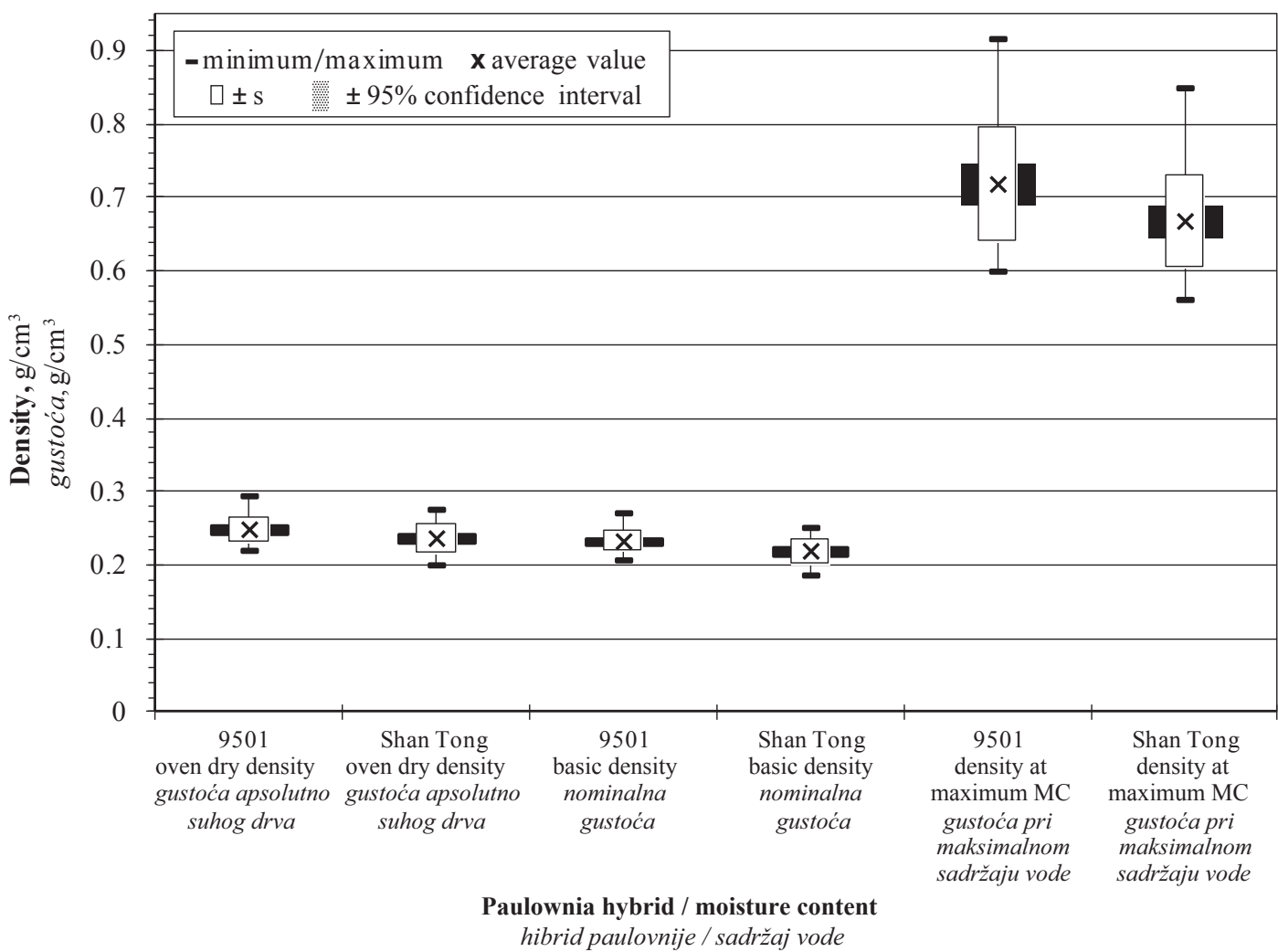

Figure 2 Statistical analyses of oven dry density, basic density and density at maximum MC, between two paulownia hybrids Slika 2. Statistička analiza gustoće u apsolutno suhom stanju, nominalne gustoće i gustoće pri maksimalnom sadržaju vode, dvaju hibrida paulovnije 
.. Sedlar, Šefc, Drvodelić, Jambreković, Kučinić, Ištok: Physical Properties of Juvenile Wood...

Table 4 Relationship between oven dry density and shrinkage of Paulownia hybrids 9051 and Shan Tong juvenile wood Tablica 4. Odnos između gustoće i utezanja juvenilnog drva hibrida paulovnije 9501 i Shan Tong

\begin{tabular}{|l|c|c|c|c|}
\hline \multicolumn{1}{|c|}{$\boldsymbol{R}$} & \multicolumn{1}{c|}{ Equation / Jednadžba } & $\boldsymbol{F}^{\mathrm{a}}$ & $\boldsymbol{p}$ \\
\hline $\begin{array}{l}\text { Relationship between oven dry density and shrinkage (9501) } \\
\text { Odnos između gustoće u apsolutno suhom stanju i utezanja (9501) }\end{array}$ & 0.02 & & $0.113^{\mathrm{NS}}$ & 0.916 \\
\hline Longitudinal shrinkage / longitudinalno utezanje & 0.4635 & & $8.751^{*}$ & 0.006 \\
\hline Radial shrinkage / radijalno utezanje & 0.3073 & & $3.334^{\mathrm{NS}}$ & 0.077 \\
\hline Tangential shrinkage / tangentno utezanje & 0.5014 & & $10.745^{*}$ & 0.003 \\
\hline Volumetric shrinkage / volumno utezanje & & \\
\hline Relationship between oven dry density and shrinkage (Shan Tong) & & $0.311^{\mathrm{NS}}$ & 0.581 \\
Odnos između gustoće u apsolutno suhom stanju i utezanja (9501) & $4.375^{*}$ & 0.045 \\
\hline Longitudinal shrinkage / longitudinalno utezanje & 0.0980 & $3.268^{\mathrm{NS}}$ & 0.080 \\
\hline Radial shrinkage / radijalno utezanje & 0.3468 & $3.609^{\mathrm{NS}}$ & 0.067 \\
\hline Tangential shrinkage / tangentno utezanje & 0.3045 & &
\end{tabular}

${ }^{\mathrm{NS}}$ not significant / nije značajno

nility of wood. Irregularity and large variations in longitudinal shrinkage were reported by many authors (Welch, 1932 and 1934; Kelsey, 1963; Hann, 1969; Skaar, 1988). Based on the work of Harris and Meylan (1965), the major cause of the variation in longitudinal shrinkage is varying microfibril angle.

Table 2 shows the comparison of investigated values of shrinkage with other authors.

In this study, regression equations between oven dry density and shrinkage, as well as, statistical significance between two properties are shown in Table 4. The relationship between oven dry density and shrinkage is statistically significant only for radial and tangential shrinkage of hybrid 9501 and radial shrinkage of hybrid Shan Tong. Negative correlation between oven dry density and longitudinal shrinkage in both hybrids was determined. Radial, tangential and volumetric shrinkage showed positive correlation with oven dry density. Measured shrinkages showed weak correlation coefficient with oven dry density, except radial and volumetric shrinkage of hybrid 9501. Similar results were reported by Šoškić et al. (2003) for Paulownia elongata and Paulownia fortunei wood.

\section{CONCLUSIONS \\ 4. ZAKLJUČAK}

Preliminary result of juvenile wood of two Paulownia hybrids showed statistically significant differences between mean values of some investigated physical properties.

Significant differences in oven dry density, basic density and density at maximum MC, between hybrid 9501 and hybrid Shan Tong were determined. However, these differences in mean values of densities amounted only to about $6 \%$.

There is no statistically significant difference in longitudinal, radial, tangential and volumetric shrinkages between the two hybrids.

Radial, tangential and volumetric shrinkage values of both investigated hybrids are similar to references for some Paulownia wood species.

Both hybrids should be investigated after five to ten years when they reach larger diameters.

\section{Acknowledgements - Zahvala}

The examined issues constitute a part of the project: Kratkoročna financijska potpora istraživanju 2018; Istraživanje strukturnih, fizičkih svojstava i biološke otpornosti drva klonova paulovnije (Shortterm financial support for research 2018; Investigation of structural and physical properties and biological resistance of Paulownia hybrids) (Paulownia Siebold et Zucc.). This work was financed by the University of Zagreb, Croatia.

\section{REFERENCES}

\section{LITERATURA}

1. Ates, S.; Ni, Y.; Akgul, M.; Tozluoglu, A., 2008: Characterization and evaluation of Paulownia elongata as a raw material for paper production. African Journal of Biotechnology, 7.

2. Akyildiz, M. H.; Kol, H. S., 2010: Some technological properties and uses of paulownia (Paulownia tomentosa Steud.) wood. Journal of Environmental Biology, 31 (3): 351-355.

3. Drvodelić, D., 2018: Propagation of Paulownia by root cuttings. Šumarski list, 5-6: 297-307. https://doi.org/10.31298/sl.142.5-6.2.

4. El-Showk, S., 2003: The Paulownia Tree. An Alternative for Sustainable Forestry, http://cropdevelopment.org/ docs/PaulowniaBooklet.pdf (Accessed Oct 1, 2019).

5. Harris, J. M.; Meylan, B. A., 1965: The influence of microfibril angle on longitudinal and tangential shrinkage in Pinus radiata. Holzforschung, 19 (5):144-153.

6. Hann, R. A., 1969: Longitudinal shrinkage in seven species of wood. U.S.D.A. forest service research note. Madison, Wisconson.

7. Icka, P.; Damo, R.; Icka, E., 2016: Paulownia tomentosa, a fast growing timber. The annals of Valahia. University of Targoviste, Trgoviste, Romania. https://doi.org/10.1515/agr-2016-0003.

8. Ištok, I.; Sedlar, T.; Šefc, B.; Sinković, T.; Perković, T., 2016: Physical Properties of Wood in Poplar Clones 'I214' and 'S1-8'. Drvna industrija, 67 (2), 163-170. https://doi.org/10.5552/drind.2016.1604.

9. Kelsey, K. E., 1963: The shrinkage-moisture content relationship for wood with special reference to longitudinal shrinkage. Australia. C.S.I. RO. Div. Forest Prod. Proj. T.P. 8, Prog. Rep. No. 2, 18 pp., Melbourne. 
10. Kiaei, M., 2013: Technological properties of Iranian cultivated paulownia wood (Paulownia fortunei). Cellulose Chemistry and Technology, 47 (9-10): 735-743.

11. Komán, S.; Feher, S.; Vityi, A., 2017: Physical and mechanical properties of Paulownia tomentosa wood planted in Hungaria. Wood Research, 62 (2): 335-340.

12. Olson, J.; Carpenter, S. B., 1982: Specific gravity, fiber length and extractive content of young paulownia. Wood and Fiber Science, 17 (4): 428-438.

13. San, H. P.; Long, L. K.; Zhang, C. Z.; Hui, T. C.; Seng, W. Y.; Lin, F. S.; Hun, A. T.; Fong, W. K., 2016: Anatomical Features, Fiber Morphological, Physical and Mechanical Properties of Three Years Old New Hybrid Paulownia: Green Paulownia. Research Journal of Forestry, 10: 30-35. https://doi.org/10.3923/rjf.2016.30.35.

14. Skaar, C., 1988: Wood-water relations. In: T. E. Timell (ed.), Springer Series in Wood Science. Springer-Verlag, Berlin, Heidelberg.

15. Šoškić, B.; Lovrić, A.; Vukovojac, B., 2003: The research of some physical properties of wood Paulownia elongata and Paulownia fortuneii. Glasnik Šumarskog fakulteta, Beograd, 87, pp. 211-221.

16. Welch, M. B., 1932: The longitudinal variation of timber during seasoning. Journal and proceedings of the Royal SOC. New South Wales, 66: 492-497.

17. Welch, M. B., 1934: The longitudinal variation of timber during seasoning. Journal and proceedings of the Royal SOC. New South Wales, 68: 249-254.

18. Vilotić, D.; Popović, J.; Mitrović, S.; Šijačić-Nikolić, M.; Ocokoljić, M.; Novović, J.; Veselinović, M., 2015: Dimensions of Mechanical Fibres in Paulownia elongata S. Y. Hu Wood from Different Habitats. Drvna industrija, 66(3): 229-234.https://doi.org/10.5552/drind.2015.1365.

19. Vusić, D.; Migalić, M.; Zečić, Ž.; Trkmić, M.; Bešlić, A.; Drvodelić, D., 2018: Fuel properties of Paulownia biomass. Proceedings of Natural resources, green technolo- gy and sustainable development. Zagreb, Croatia, 5-8 6 . 2018, pp. 126-130.

20. Zhao-Hua, Z.; Ching-Ju, C.; Xin-Yu, L.; Yao Gao, X., 1986: Paulownia in China: Cultivation and Utilization. Asian Network for Biological Sciences and International Development Research Centre, Beijing, China.

21. *** HRN ISO 3129, 2015: Drvo - Metode uzorkovanja i opći zahtjevi za ispitivanje fizikalnih i mehaničkih svojstava na manjim uzorcima masivnog drva

22. *** HRN ISO 13061-1, 2015: Fizikalna i mehanička svojstva drva - Metode ispitivanja za manje uzorke masivnog drva, 1. dio: Određivanje sadržaja vode za provođenje ispitivanja fizikalnih i mehaničkih svojstava.

23. *** HRN ISO 13061-2, 2015: Fizikalna i mehanička svojstva drva - Metode ispitivanja za manje uzorke masivnog drva, 2. dio: Određivanje gustoće za provođenje ispitivanja fizikalnih i mehaničkih svojstava.

24. *** ISO 13061-13, 2016: Physical and mechanical properties of wood - Test methods for small clear wood specimens, Part 13: Determination of radial and tangential shrinkage.

25. *** ISO 13061-14, 2016: Physical and mechanical properties of wood - Test methods for small clear wood specimens, Part 14: Determination of volumetric shrinkage.

\section{Corresponding address:}

Assoc. Prof. BOGOSLAV ŠEFC, PhD

University of Zagreb

Faculty of Forestry

Svetošimunska 25, 10000 Zagreb, CROATIA

e-mail: bsefc@sumfak.hr 